\title{
TINGKAT KEPUASAN DAN ASUPAN ZAT GIZI MAKRO DENGAN STATUS GIZI REMAJA PUTRI
}

\author{
The level of satisfaction and macro nutrition with adolescent nutrition status
}

\author{
Wahyuni Sulistiawati, Rudy Hartono, Thresia Dewi Kartini B \\ Jurusan Gizi Politeknik Kesehatan Makassar
}

\begin{abstract}
ABSTRAK
Pondok pesantren merupakan salah satu institusi yang melayani kebutuhan makan santri, sehingga harus memiliki sistem penyelenggaraan makanan yang baik. Makanan dikatakan bergizi jika mengandung zat makanan yang cukup sesuai dengan kebutuhan tubuh. Penelitian ini bertujuan untuk mengetahui hubungan antara tingkat kepuasan dan asupan zat gizi makro dengan status gizi remaja putri di pondok pesantren Nahdlatul Ulum Maros.Penelitian ini merupakan penelitian analitik. Sampel adalah remaja putri SMP kelas VII dan VIII yang berjumlah 95 orang yang dipilih secara purposive sampling. Tingkat kepuasan diperoleh menggunakan kuesioner diolah secara manual menggunakan scoring. Asupan zat gizi makro diperoleh melalui recall $2 \times 24$ jam tidak berturutan kemudian diolah menggunakan nutri 2008 dan dibandingkan dengan angka kebutuhan gisi (AKG). Status gizi diperoleh melalui pengukuran antropometri. Hubungan antara variabel tingkat kepuasan dan asupan zat gizi makro dengan status gizi dilakukan uji Chi Square. Data disajikan menggunakan tabel frekuensi dan narasi. Hasil penelitian menunjukkan bahwa sampel yang menyukai hidangan nasi 67 orang $(70,5 \%)$, lauk hewani 70 orang $(73,7 \%)$, lauk nabati 67 orang $(70,5 \%)$, sayur 70 orang $(73,7 \%)$, dan tingkat kepuasan pada makanan 85 orang $(89,5 \%)$. Sampel yang memiliki asupan protein baik 95 orang $(100 \%)$, asupan lemak baik 49 orang $(51,6 \%)$ dan asupan karbohidrat kurang 79 orang $(83,2 \%)$. Status gizi sampel 49 orang $(51,6 \%)$ normal berdasarkan IMT/U. Hasil uji statistik disimpulkan bahwa tidak terdapat hubungan yang signifikan antara tingkat kepuasan dan asupan zat gizi makro dengan status gizi remaja putri di Pondok Pesantren Nahdlatul Ulum Maros.
\end{abstract}

\section{PENDAHULUAN}

Pesantren diartikan sebagai asrama, tempat santri, atau tempat murid-murid belajar mengaji. Istilah pesantren adalah lembaga pendidikan Islam, dimana para santri biasanya tinggal di pondok (asrama) dengan materi pengajaran kitab-kitab klasik dan kitab-kitab umum, bertujuan untuk menguasai ilmu agama Islam secara detail, serta mengamalkannya sebagai pedoman hidup keseharian dengan menekankan pentingnya moral dalam kehidupan bermasyarakat. Umumnya santri-santri yang berada di pondok pesantren sama saja dengan anak didik di sekolah-sekolah umum yang merupakan sumber daya yang menjadi generasi penerus pembangunan yang perlu mendapat perhatian khusus terutama kesehatan dan pertumbuhannya. Salah satu aspek yang mendukung hal tersebut adalah pemenuhan kebutuhan gizi bagi para santri (Khasanah, 2010).

Pondok pesantren merupakan salah satu institusi yang melayani kebutuhan makan santri, sehingga harus memiliki sistem penyelenggaraan makanan yang baik agar dapat tercipta kualitas sumber daya manusia yang tinggi karena gizi merupakan salah satu penentu kesehatan santri. Hal ini penting karena sebagian besar santri putri usia remaja di pondok pesantren tersebut adalah anak usia sekolah yang merupakan generasi penerus tumpuan harapan bangsa yang harus dipersiapkan kualitasnya dengan baik (Sutardji, 2007). Pondok Pesantren Putri Nahdlatul Ulum Maros merupakan salah satu institusi pendidikan yang menyelenggarakan makanan selama pendidikan. Penyelenggaraan makanan yang dilakukan tidak menggunakan jasa catering tetapi dilakukan langsung oleh pihak sekolah.

Usia remaja (10-18 tahun) merupakan periode rentan gizi karena berbagai sebab. Pertama, remaja memerlukan zat gizi yang lebih tinggi karena peningkatan pertumbuhan fisik dan perkembangan yang drastis. Kedua, perubahan gaya hidup dan kebiasaan makan remaja mempengaruhi baik asupan maupun kebutuhan gizinya. Ketiga, aktif dalam olahraga (Almatsier, 2011).

Makanan dikatakan bergizi jika mengandung zat makanan yang cukup dalam jumlah dan kualitasnya sesuai dengan kebutuhan tubuh. Makanan yang 
kita konsumsi setiap hari dapat dibagi dalam beberapa golongan, yaitu protein, lemak, karbohidrat, vitamin, mineral, dan air. Sumber energi dalam bahan makanan dapat diperoleh dari zat gizi makro yaitu karbohidrat, lemak dan protein (Irianto, 2010).

Rata-rata kecukupan konsumsi energi penduduk umur 13-15 tahun (usia pra remaja) sebanyak $54,5 \%$ mengkonsumsi energi di bawah kebutuhan minimal dan yang mengkonsumsi protein di bawah kebutuhan minimal adalah 38,1\%. Ratarata kecukupan konsumsi energi penduduk umur 16-18 tahun (usia remaja) sebanyak $54,5 \%$ di bawah kebutuhan minimal dan kecukupan konsumsi protein di bawah kebutuhan minimal adalah 35,6\% (Riskesdas, 2010).

Berdasarkan uraian di atas peneliti tertarik untuk meneliti di tempat tersebut dan juga karena belum ada penelitian tentang hubungan tingkat kepuasan dan asupan zat gizi makro dengan status gizi remaja putri di Pondok Pesantren Nahdlatul Ulum Maros.

\section{METODE}

\section{Desain, tempat dan waktu}

penelitian survei analitik dengan menggunakan rancangan cross sectional. Penelitian dilakukan di Pondok Pesantren Nahdlatul Ulum Maros. Penelitian dilaksanakan mulai dari bulan Desember 2017 sampai dengan Juli 2018.

\section{Jumlah dan cara pengambilan sampel} Populasi ialah semua remaja putri yang berada di Pondok pesantren Nahdlatul Ulum Maros dengan jumlah 125 orang. Sampel ialah seluruh remaja putri SMP di Pondok Pesantren Nahdlatul Ulum Maros denganKriteria sampel :Bersedia menjadi sampel, santriwati yang menetap di asrama pondok pesantren Nahdlatul Ulum Maros, sehat jasmani dan rohani, mengisi kuesioner dengan lengkap dan benar sesuai dengan format yang diberikan. Besar sampel 95 orang dan cara pengambilan sampel menggunakan metode Purposive Sampling.

\section{Jenis dan Cara Pengumpulan Data}

1. Data Primer

a. Tingkat kepuasan

Data tingkat kepuasan dikumpulkan melalui wawancara langsung dengan responden menggunakan kuesioner tingkat kepuasan terhadap makanan yang dikonsumsi di asrama pondok pesantren Nahdlatul Ulum Maros mulai dari penilaian warna, aaroma, rasa dan porsi pada makanan.

b. Asupan zat gizi makro Data asupan zat gizi makro diperoleh melalui wawancara menggunakan kuesioner recall 24 jam. Pengambilan data dilakukan sebanyak 2 kali dengan menggunakan metode food recall $2 \times 24$ jam tidak berturutturut.

c. Status gizi

Data status gizi diperoleh melalui pengukuran langsung terhadap responden yaitu dengan menggunakan timbangan digital dan microtoice untuk memeroleh data berat badan dan tinggi badan responden.

2. Data Sekunder

Data sekunder diperoleh dari bagian administrasi Pondok Pesantren Putri Nahdlatul Ulum Maros yaitu jumlah siswa dan profil sekolah.

\section{Pengolahan dan Analisis Data}

1. Pengolahan Data

a. Tingkat kepuasan santri

Data tingkat kepuasan santri pada penyelenggaraan makanan yang dialami dan dirasa diolah secara manual dengan menggunakan scoring terhadap warna, aroma, rasa dan porsi pada makanan.

b. Asupan zat gizi makro Data asupan zat gizi diolah menggunakan aplikasi 
nutria 2008 dan hasilnya akan dibandingakan dengan kebutuhan AKG.

c. Status gizi

Data status gizi diolah dengan menggunakan rumus IMT. Kategori status gizi ditentukan berdasarkan kriteria objektif yaitu : Kurus : 17-18,4 $\mathrm{TB} / \mathrm{m}^{2}$, dan Normal : $18,5-27 \mathrm{~TB} / \mathrm{m}^{2}$.

2. Analisis dan Penyajian Data

Data dianalisis menggunakan uji Chi Square untuk menganalisis hubungan antar variabel yang diteliti yaitu tingkat kepuasan dan status gizi serta asupan zat gizi makro dan status gizi dan disajikan dengan menggunakan tabel dan narasi.

\section{HASIL}

Karakteristik sampel, Sampel pada penelitian ini adalah Santriwati SMP di Pondok Pesantren Nahdlatul Ulum Maros yaitu kelas VII dan kelas VIII. Sampel ini terdiri dari 95 siswi yang dipilih secara acak. Hasil penelitian diperoleh karakteristik sebagai berikut. Tabel 1 menunjukkan bahwa sampe pada penelitian ini yaitu berumur 14 tahun sebanyak 54 orang $(57 \%)$ dan berada di kelas VIII sebanyak 48 orang (51\%).

Tabel 02 menunjukkan bahwa tingkat kepuasan sampel pada nasi yang suka 67 orang $(70,5 \%)$, lauk hewani suka 70 orang $(73,7 \%)$, lauk nabati suka 67 orang $(70,5 \%)$ dan sayur suka 70 orang (73,7\%).

Tabel 03 menunjukkan bahwa sampel yang memiliki tingkat kepuasan terhadap makanan yaitu sebanyak 85 orang $(89,5 \%)$.

Tabel 04 menunjukkan bahwa sampel yang memiliki asupan lemak baik sebanyak 49 orang $(51,6 \%)$ dan asupan karbohidrat kurang sebanyak 79 orang $(83,2 \%)$.

Tabel 05 menunjukkan sampel yang memiliki status gizi normal sebanyak 49 orang $(51,6 \%)$.

Tabel 06 menunjukkan bahwa sampel yang suka hidangan nasi status gizi normal 36 orang $(37,9 \%)$, suka lauk hewani status gizi normal 35 orang $(36,8 \%)$, suka lauk nabati status gizi kurus 34 orang $(35,8 \%)$, dan suka sayur status gizi normal 37 orang $(73,7 \%)$.

Tabel 07 menunjukkan bahwa sampel yang menyukai hidangan makanan sebanyak 39 orang $(41,1 \%)$ yang berstatus gizi kurus dan 46 orang $(48,4 \%)$ yang berstatus gizi normal.

Tabel 08 menunjukkan bahwa sampe yang memiliki asupan protein baik status gizi normal 49 orang $(51,6 \%)$, asupan lemak baik status gizi normal 27 orang $(28,4 \%)$ dan asupan karbohidrat kurang status gizi normal 42 orang $(44,2 \%)$.

\section{PEMBAHASAN}

Tingkat kepuasan

a. Nasi dan Status Gizi

Penelitian yang dilakukan didapatkan bahwa santri yang menyukai hidangan nasi sebanyak 67 orang $(70,5 \%)$ dan yang tidak menyukai sebanyak 28 orang $(29,5 \%)$. Aspek penelitian ini meliputi aspek warna, aroma, rasa dan porsi makanan yang disajikan. Hal ini sejalan dengan penelitian Diahningtias (2016) yang menyatakan bahwa tingkat kepuasan santri pada hidangan nasi sebanyak $55 \%$.

Uji statistik yang dilakukan diperoleh bahwa, tidak ada hubungan yang signifikan antara tingkat kepuasan pada aspek nasi dan status gizi dengan nilai $p=0,671$. Hal ini disebabkan karena porsi makanan yang diberikan kepada santri cenderung sama, suhu makanan kurang hangat sehingga kurang membangkitkan selera makan.

b. Lauk Hewani dan Status Gizi Penelitian yang dilakukan didapatkan bahwa santri yang menyukai hidangan lauk hewani sebanyak 70 orang $(73,7 \%)$ dan yang tidak menyukai sebanyak 25 orang $(26,3 \%)$. Hidangan yang disajikan adalah menu ikan kuah kuning ikan goreng dan telur mata sapi, aspek penelitian ini meliputi aspek warna, aroma, rasa dan porsi makanan yang disajikan. Hal ini sejalan dengan penelitian Diahningtias (2016) yang menyatakan bahwa tingkat kepuasan 
santri pada hidangan lauk hewani sebanyak $79 \%$.

Uji statistik yang dilakukan diperoleh bahwa, tidak ada hubungan yang signifikan antara tingkat kepuasan pada aspek lauk hewani dan status gizi dengan nilai $p=0,778$. $\mathrm{Hal}$ ini disebabkan cara pengolahan menu yang kurang bervariasi dan menu yang sering berulang .

c. Lauk Nabati dan Status Gizi

$$
\text { Penelitian yang dilakukan }
$$
didapatkan bahwa santri yang menyukai hidangan lauk nabati sebanyak 67 orang $(70,5 \%)$ dan yang tidak menyukai sebanyak 28 orang (29,5\%). Hidangan yang disajikan adalah menu sambal goreng, aspek penelitian ini meliputi aspek warna, aroma, rasa dan porsi makanan yang disajikan. Hal ini sejalan dengan penelitian Diahningtias (2016) yang menyatakan bahwa tingkat kepuasan santri pada hidangan lauk nabati sebanyak $70 \%$.

Uji statistik yang dilakukan diperoleh bahwa, tidak ada hubungan yang signifikan antara tingkat kepuasan pada aspek lauk nabati dan status gizi dengan nilai $p=0,634$. Hal ini disebabkan karena porsi makanan yang diberikan kepada santri cenderung sama dan menu yang kurang bervariasi sehingga menyebabkan kejenuhan bagi santri.

\section{d. Sayur dan Status Gizi}

Penelitian yang dilakukan didapatkan bahwa santri yang menyukai hidangan sayur sebanyak 70 orang $(73,7 \%)$ dan yang tidak menyukai sebanyak 35 orang $(26,3 \%)$. Hidangan yang disajikan adalah menu sayur bening, sayur tumis, sayur daun ubi dan sayur sop, aspek penelitian ini meliputi aspek warna, aroma, rasa dan porsi makanan yang disajikan. Hal ini sejalan dengan penelitian Diahningtias (2016) yang menyatakan bahwa tingkat kepuasan santri pada hidangan sayur sebanyak $92 \%$.

Uji statistik yang dilakukan diperoleh bahwa, tidak ada hubungan yang signifikan antara tingkat kepuasan pada aspek sayur dan status gizi dengan nilai $p=0,854$. Hal ini disebabkan karena beberapa santri kurang menyukai sayur dan lebih memilih menikmat hidangan makanan tanpa mengambil hidangan sayur yang disediakan. Berdasarkan wawancara dengan para santri beberapa santri mengemukakan bahwa terkadang hidangan sayur yang disediakan terasa hambar sehingga kurang dinikmati oleh para santri.

e. Tingkat Kepuasan Makanan dan Status Gizi

Penelitian yang dilakukan didapatkan bahwa santri yang menyukai hidangan makanan sebanyak 85 orang $(89,5 \%)$ dan yang tidak menyukai sebanyak 15 orang $(10,5 \%)$. Aspek penelitian ini meliputi aspek warna, aroma, rasa dan porsi makanan yang disajikan. $\mathrm{Hal}$ ini sejalan dengan penelitian Diahningtias (2016) yang menyatakan bahwa tingkat kepuasan santri pada hidangan makanan sebanyak $92 \%$.

Uji statistik yang dilakukan diperoleh bahwa, tidak ada hubungan yang signifikan antara tingkat kepuasan pada makanan dan status gizi dengan nilai $p=0,264$. Hal ini disebabkan karena makanan yang disajikan oleh pihak pesantren kurang bervariasi dan pemberian porsi pada tiap makanan relative sama.

Asupan Zat Gizi Makro

a. Asupan Protein dan Status Gizi Hasil penelitian yang dilakukan didapatkan bahwa asupan protein santri di Pondok Pesantren Nahdlatul Ulum Maros tergolong baik 46 orang $(48,4 \%)$ dengan status gizi kurus dan 49 orang $(51,6 \%)$ dengan status gizi normal. Hal ini sejalan dengan penelitian Amalia, (2013) yang dilakukan di Pondok Pesantren Hidayatullah Makassar yang menunjukkan asupan protein yang kurang sebanyak 34 orang $(34 \%)$ dan 66 orang $(66 \%)$ yang memiliki asupan protein yang baik. 
b. Asupan Lemak dan Status Gizi Hasil penelitian yang dilakukan didapatkan bahwa asupan lemak santri di Pondok Pesantren Nahdlatul Ulum Maros tergolong kurang yaitu sebanyak 46 orang $(48,4 \%)$ dengan 24 orang $(25,3 \%)$ yang berstatus gizi kurus dan 22 orang $(23,2 \%)$ berstatus gizi normal, sedangkan asupan lemak yang tergolong baik yaitu sebanyak 49 orang $(51,6 \%)$ dengan 22 orang $(23,2 \%)$ yang berstatus gizi kurus dan 27 orang $(28,4 \%)$ berstatus gizi normal. Hal ini sejalan dengan penelitian Amalia, (2013) yang dilakukan di Pondok Pesantren Hidayatullah Makassar yang menunjukkan asupan lemak yang kurang sebanyak 10 orang (10\%) dan 90 orang $(90 \%)$ yang memiliki asupan lemak yang baik.

Uji statistik yang dilakukan diperoleh bahwa, tidak ada hubungan yang signifikan antara asupan lemak dan status gizi dengan nilai $p=0,614$. Kebutuhan gizi setiap orang berbeda tergantung jenis kelamin, usia dan kondisi tubuh (Susanti,2012). Di Pondok Pesantren Nahdlatul Ulum Maros menyediakan makanan dengan porsi yang sama ke pada setiap santri sehingga mempengaruhi pemenuhan asupan zat gizi.

c. Asupan Karbohidrat dan Status Gizi Hasil penelitian yang dilakukan didapatkan bahwa asupan karbohidrat santri di Pondok Pesantren Nahdlatul Ulum Maros yaitu tergolong kurang yaitu sebanyak 79 orang $(83,2 \%)$ dengan 37 orang $(38,9 \%)$ yang berstatus gizi kurus dan 42 orang $(44,2 \%)$ berstatus gizi normal, sedangkan asupan karbohidrat yang tergolong baik yaitu sebanyak 16 orang $(16,8 \%)$ dengan 9 orang $(9,5 \%)$ yang berstatus gizi kurus dan 7 gorang $(7,3 \%)$ berstatus gizi normal. Hal ini sejalan dengan penelitian Amalia, (2013) yang dilakukan di Pondok Pesantren Hidayatullah Makassar yang menunjukkan asupan karbohidrat yang kurang sebanyak 99 orang
(99\%) dan 1 orang (1\%) yang memiliki asupan karbohidrat yang baik.

Uji statistik yang dilakukan diperoleh bahwa, tidak ada hubungan yang signifikan antara asupan energi dan status gizi dengan nilai $p=0,680$. Konsumsi energi dan zat gizi yang rendah bukan disebabkan oleh daya terima yang terlihat dari kesukaan santri terhadap makanan pesantren, akan tetapi dapat disebabkan oleh faktor lain seperti makanan yang disediakan oleh pesantren masih kurang atau belum dapat mencukupi dengan kebutuhan sehingga para santri.

Kelemahan dari penelitian ini adalah tidak dilakukan validasi terhadap kuesioner yang diberikan kepada sampel sehingga menyebabkan kemungkinan data kurang akurat.

\section{KESIMPULAN}

Sampel yang menyukai hidangan nasi 67 orang (70,5\%), lauk hewani 70 orang $(73,7 \%)$, lauk nabati 67 orang $(70,5 \%)$, sayur 70 orang $(73,7 \%)$, dan tingkat kepuasan pada makanan 85 orang $(89,5 \%)$. Sampel yang memiliki asupan protein baik 95 orang $(100 \%)$, asupan lemak baik 49 orang $(51,6 \%)$ dan asupan karbohidrat kurang 79 orang $(83,2 \%)$. Status gizi sampel 49 orang $(51,6 \%)$ normal berdasarkan IMT/U. Hasil uji statistik disimpulkan bahwa tidak terdapat hubungan yang signifikan antara tingkat kepuasan dan asupan zat gizi makro dengan status gizi remaja putri di Pondok Pesantren Nahdlatul Ulum Maros.

\section{SARAN}

Sampel diberikan edukasi tentang pola makan dan pengetahuan zat-zat gizi makro agar kebutuhan terhadap zat gizi makro terpenuhi. Bagi penyelenggara Pesantren Nahdlatul Ulum Maros sebaiknya pada siklus menu ditambahkan buah. Lebih memberikan varias pada menu yang disajikan seperti yang telah peneliti buat (pada lampiran 7). Perlu dilakukan validasi pada kuesioer yang akan diberikan sehingga hasil penelitian lebih akurat. 


\section{DAFTAR PUSTAKA}

Almatsier. 2011. Gizi Seimbang Dalam Daur Kehidupan. Jakarta: Gramedia Pustaka Utama.

Amalia, Rezki. 2013. Hubungan Asupan Energi Dan Zat Gizi Dengan Status Gizi Santri Putri Yayasan Pondok Pesantren Hidayatullah Makassar Sulawesi Selatan Tahun 2013. Makassar. Unhas.

Diahtingningsih, Utami. 2016. Analisis Penyelenggaraan Makanan, Tingkat Kesukaan, dan Tingkat Kecukupan energy dan Zat Gizi Santri di Pesantren Al-Hamidiyah Depok. Bogor. IPB
Irianto, 2010. Pencegahan Infeksi Nosokomial di Rumah Sakit. Yogyakarta: Kanisius.

Khasanah. 2010. Perubahan Perilaku Sebagai Dampak Adanya Promosi Kesehatan. Surabaya. FK UNAIR.

Riset Kesehatan Dasar. (2010). Jakarta: Badan Penelitian dan Pengembangan Kesehatan Kementrian Kesehatan RI.

Sutardji dan Azinar, M. 2007. Tingkat konsumsi energi dan konsumsi protein Serta hubungannya dengan status gizi anak asuh Usia 10-18 tahun (studi pada penyelenggaraan makanan di panti Asuhan pamardi putra kabupaten demak. 
Tabel 01

Karakteristik sampel

\begin{tabular}{lll}
\hline Karakteristik & $\mathrm{n}$ & $\%$ \\
\hline Umur & 41 & 43 \\
13 tahun & 54 & 57 \\
14 tahun & & \\
& & 49 \\
Kelas & 47 & 51 \\
VIIII & 48 & \\
\hline
\end{tabular}

Tabel 02

Tingkat Kepuasan di Pondok Pesantren Nahdlatul Ulum Maros

\begin{tabular}{lcc}
\hline \multicolumn{1}{c}{ Tingkat Kepuasan } & $\mathrm{n}$ & $\%$ \\
\hline Nasi & 67 & \\
Suka & 28 & 70,5 \\
Tidak suka & & 29,5 \\
& & \\
Lauk Hewani & 70 & 73,7 \\
Suka & 25 & 26,3 \\
Tidak suka & & \\
\hline Lauk Nabati & 67 & 70,5 \\
Suka & 28 & 29,5 \\
Tidak suka & & \\
& & 73,7 \\
Sayur & 70 & 26,3 \\
Suka & 25 &
\end{tabular}

Tabel 03

Tingkat Kepuasan Pada Makanan di Pondok Pesantren Nahdlatul Ulum Maros

\begin{tabular}{lll}
\hline \multicolumn{1}{c}{ Makanan } & $\mathrm{n}$ & $\%$ \\
\hline Suka & 85 & 89,5 \\
Tidak suka & 10 & 10,5 \\
\hline
\end{tabular}

Tabel 04

Asupan Zat Gizi Makro di Pondok Pesantren Nahdlatul Ulum Maros

\begin{tabular}{lcc}
\hline \hline Asupan Zat Gizi & $\mathrm{n}$ & $\%$ \\
\hline Lemak & & \\
Baik & 49 & 51,6 \\
Kurang & 46 & 48,4 \\
\hline
\end{tabular}




\begin{tabular}{lrr}
\hline Karbohidrat & & \\
Baik & 16 & 16,8 \\
Kurang & 79 & 83,2 \\
\hline
\end{tabular}

Tabel 05

Status Gizi di PondokPesantren Nahdlatul Ulum Maros

\begin{tabular}{ccc}
\hline \hline Status Gizi & $\mathrm{n}$ & $\%$ \\
\hline Kurus & 46 & 48,4 \\
Normal & 49 & 51,6 \\
\hline
\end{tabular}

Tabel 06

Hubungan Tingkat Kepuasan dan Status Gizi

di Pondok Pesantren Nahdlatul Ulum Maros

\begin{tabular}{lcccc}
\hline \multirow{2}{*}{ Tingkat Kepuasan } & \multicolumn{3}{c}{ Status gizi } & \multicolumn{2}{c}{ Total } \\
\cline { 2 - 5 } & Kurus & Normal & $\mathrm{n}$ & $\%$ \\
\hline Nasi & & & & \\
Suka & 31 & 36 & 67 & 70,5 \\
Tidak suka & 15 & 13 & 28 & 29,5 \\
& & & & \\
\hline Lauk Hewani & & & & \\
Suka & 35 & 35 & 70 & 73,7 \\
Tidak suka & 11 & 14 & 25 & 26,3 \\
& & & & \\
& & & & \\
Lauk Nabati & 34 & 33 & 70 & 70,5 \\
Suka & 12 & 16 & 25 & 29,5 \\
Tidak suka & & & & \\
& & & & \\
\hline Sayur & 33 & 37 & 70 & 73,7 \\
Suka & 13 & 12 & 25 & 26,3 \\
Tidak suka & & & & \\
& & & & \\
\hline
\end{tabular}

Tabel 07

Hubungan Tingkat Kepuasan Makanan dan Status Gizi

di Pondok Pesantren Nahdlatul Ulum Maros

\begin{tabular}{lcccc}
\hline \hline \multirow{2}{*}{ Makanan } & \multicolumn{2}{c}{ Status gizi } & \multicolumn{2}{c}{ Total } \\
\cline { 2 - 5 } & Kurus & Normal & $\mathrm{n}$ & $\%$ \\
\hline Suka & 39 & 46 & 85 & 89,5 \\
Tidak suka & 7 & 3 & 15 & 10, \\
\hline
\end{tabular}


Tabel 08

Hubungan Asupan Zat Gizi Makro dan Status Gizi di Pondok Pesantren Nahdlatul Ulum Maros

\begin{tabular}{lcccc}
\hline \multirow{2}{*}{ Zat Gizi Makro } & \multicolumn{2}{c}{ Status gizi } & \multicolumn{2}{c}{ Total } \\
\cline { 2 - 5 } & Kurus & Normal & $\mathrm{n}$ & $\%$ \\
\hline Protein & 46 & 49 & 95 & 100 \\
$\begin{array}{l}\text { Baik } \\
\text { Kurang }\end{array}$ & - & - & - & - \\
\hline Lemak & 22 & 27 & 49 & 51,6 \\
Baik & 24 & 22 & 46 & 48,4 \\
Kurang & 9 & 7 & 16 & 16,8 \\
\hline Karbohidrat & 37 & 42 & 79 & 83,2 \\
Baik & & & & \\
Kurang & & & & \\
\hline
\end{tabular}

